\title{
METODE I'RĀB AL-QUR'AN DAN KONVENSIONAL SEBAGAI PEMBELAJARAN BAHASA ARAB BAGI NON ARAB DI PONPES AL MADINAH BOYOLALI
}

\author{
Syamsul Hidayat ${ }^{1}$, Amien Ashiddiqi ${ }^{2}$ \\ ${ }^{1}$ Universitas Muhammadiyah Surakarta \\ ${ }^{2}$ PPMI (Pondok Pesantren Modern Islam Assalam) Pabelan Kartasura Sukoharjo \\ E-Mail: syamsul.hidayat@ums.ac.id, amienashiddiqi@gmail.com
}

\begin{abstract}
This study aims to obtain related information about (1) Exploring and knowing Arabic learning models for non-Arabs, (2) Knowing the differences between the i'räb alQur'an (IQ) method and the conventional method (MK) for non-Arab speakers, (3) Knowing and describing the level of effectiveness of Arabic learning for non-Arabs using the i'rāb alQur'an (IQ) method and the conventional method (MK) in Islamic boarding schools. This research includes qualitative research at Al Madinah Islamic Boarding School Class XI MA Nogosari Boyolali Year 2017. The research subjects are the principal, teachers and students. Data collection is done through observation, interviews, and documentation. The data analysis technique carried out in this study is to analyze interactive model data by interacting between data collection, data reduction, data presentation and data verification. Research results: (1) Arabic Language Learning Model of Madrasah Aliyah Al Madinah Boyolali 2017/2018. The basic method used by the cleric is the bandongan method, which is a collective method (halaqoh) which is conveyed by the translation model in which the cleric reads the Arabic-language book, then translates and explains the rules and wisdom contained in it, while the students listen to the study delivered by the cleric. Learning uses the method of translation rules, delivery with lecturer, question-answer and talaqqi (sorogan). (2) The difference between the IQ method and the conventional method that the IQ method is applied in the boarding school environment in nahwu-saraf, balāgah learning, and some in mutāla'ah lessons. The IQ method is more inviting students to interact directly with the al-Qur'an and Hadith. The IQ method is broader in discussion, while conventional methods are limited to the curriculum. (3) The level of effectiveness of learning Arabic for non-Arabs with the IQ method and conventional methods in Islamic boarding schools that conventional methods are less satisfying for balägah and mutâla'ah lessons, if there is no combination of strategies.
\end{abstract}

Keywords: Learning Model; I'rab al-Qur'an Method; Conventional

Abstrak: Penelitian ini bertujuan untuk mendapatkan informasi terkait tentang (1) Mengeksplorasi dan mengetahui model pembelajaran bahasa Arab bagi non-Arab, (2) Mengetahui perbedaan antara metode i'rāb al-Qur'an (IQ) dengan metode konvensional (MK) bagi penutur non-Arab, (3) Mengetahui dan mendeskripsikan tingkat efektifitas pembelajaran bahasa Arab untuk non-Arab dengan metode IQ dan MK di lingkungan pondok pesantren. Penelitian ini termasuk penelitian kualitatif di Pondok Pesantren Al Madinah Kelas XI MA Nogosari Boyolali Tahun 2017. Subjek penelitian dari kepala sekolah, guru, dan siswa. Pengumpulan data dilakukan melalui observasi, wawancara, dan dokumentasi. Teknik analisis data yang dilakukan pada penelitian ini adalah teknik analisis data model interaktif dengan menginteraksikan antara pengumpulan data, reduksi data, penyajian data dan verifikasi data. Hasil penelitian: (1) Model Pembelajaran Bahasa Arab Madrasah Aliyah Al Madinah Boyolali Tahun 2017/2018. Metode yang digunakan para ustadz adalah metode talaqqi (sorogan-bandongan) yaitu metode kolektif (halaqoh) penyampaiannya dengan model 
kaidah-terjemah yang mana ustadz membaca kitab berbahasa Arab, lalu menerjemahkan dan menjelaskan kaidah-kaidah dan hikmah yang terkandung di dalamnya, sementara para santri menyimak kajian yang disampaikan ustadz. Pembelajaran menggunakan metode kaidah-terjemah, penyampaian dengan lecturer (ceramah), dan tanya-jawab. (2) Perbedaan antara metode i'rāb al-Qur'an dengan metode konvensional bahwa metode IQ diterapkan di lingkungan pondok pesantren dalam pembelajaran nahwu-șaraf, balāgah, dan beberapa di pelajaran mutāla'ah. Metode IQ lebih mengajak siswa berinteraksi secara langsung kepada alQur'an maupun Hadits. Metode IQ lebih mudah diingat siswa dan lebih luas pembahasannya, adapun MK terbatas dengan kitab kurikulum pegangan. (3) Tingkat efektifitas pembelajaran bahasa Arab untuk non-Arab dengan metode IQ dan MK di lingkungan pondok pesantren bahwa metode konvensional kurang memuaskan untuk pelajaran balāgah dan muțāla'ah, jika tidak ada kombinasi strategi.

Kata Kunci: Model Pembelajaran; Metode I'rab al-Qur'an; Konvensional

\section{PENDAHULUAN}

Al-Qur'an merupakan ayāt qauliyah, sumber ilmu, petunjuk, dan pedoman bagi orang yang beriman dan berakal. Allah -'Azza wa Jalla- telah menurunkannya dalam sebuah bacaan yang berbahasa Arab tanpa cacat dan keraguan di dalamnya, serta relevan di setiap zaman dan tempat. Allah-Jalla wa 'Alā- berfirman:

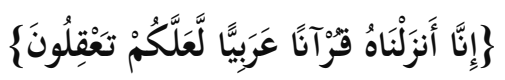

"Sesungguhnya Kami menurunkan alQur'an dalam bahasa Arab agar kalian memahaminya." (QS. Yusuf /12: 2) ${ }^{1}$.

Berkata Ibnu Katsir -rahimahullahdalam tafsirnya (yang artinya): "Bahasa Arab adalah bahasa paling fasih, jelas, dan luas cakupannya, serta paling banyak perbendaharaan kata dalam mengungkapkan makna-makna yang merasuk jiwa-jiwa manusia, karena itulah Allah -'Azza wa Jalla- menurunkan KitabNya yang paling mulia dengan bahasa yang paling mulia di antara bahasa-bahasa lainnya yang disampaikan-Nya kepada rasul yang paling mulia, juga melalui perantaraan malaikat yang paling mulia, penurunannya terjadi di belahan bumi yang paling mulia, serta awal penurunannya (al-Qur'an) terjadi

1 Yayasan Penyelenggara Penterjemah/Pentafsir Al Qur'an, Al-Quran dan Terjemahnya, (Saudi: Percetakan Raja Fahd, 1971), hlm. 348. di dalam bulan yang paling mulia, yaitu bulan Ramadan; sehingga sempurnalah kitab al-Qur'an ini dari berbagai seginya. ${ }^{2 \prime}$

Tidak terbatas pedoman bagi umat Islam saja, bahkan beberapa ilmuwan dunia terpanggil dengan al-Qur'an yang menakjubkan ini, sehingga mereka rela "menguras keringat" untuk terus mencari celah di dalamnya; namun penemuan demi penemuan yang telah berhasil mereka dapatkan justru mengungkap rahasiarahasia yang terkandung di dalamnya dan semakin menambah bukti atas kebenaran al-Qur'an yang disampaikan kepada RasulNya yang "ummi" beserta keagungan Allah Sang Pencipta, meskipun hingga kini masih banyak hal misteri yang tersembunyi yang masih belum terpecahkan. Sebagaimana tersirat dalam firman-Nya:

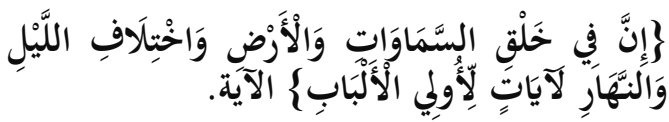

"Sesungguhnya pada penciptaan langit dan bumi, serta pergantian malam dan siang, menjadi tanda-tanda (bukti-bukti atas kekuasaan Allah) bagi orang-orang yang berakal." (QS. Al-'Imrān/3: 190). ${ }^{3}$

Islam, al-Qur'an, dan bahasa Arab

2 Ibnu Katsīr, Tafsìr al-Qur'an al- 'Adzhīm, (Jeddah: Maktabah Jeddah), Hal. 2/239.

3 Yayasan Penyelenggara Penterjemah/Pentafsir Al-Qur'an, Al-Quran dan Terjemahnya, (Saudi: Percetakan Raja Fahd, 1971), hlm. 109. 
adalah satu tubuh yang saling berhubungan dan saling menguatkan, tidak bisa dipisahkan antara anggota satu dengan lainnya. ${ }^{4}$ Mempelajari bahasa Arab merupakan syarat wajib seorang muslim untuk mengerti isi kandungan al-Qur'an, ${ }^{5}$ dan ketika seseorang mempelajari bahasa al-Qur'an, al-Sunnah, maupun al-āisàr secara otomatis orang tersebut mempelajari bahasa Arab, mengkaji sumber ilmu, sekaligus ikut andil menjaga kemurnian Islam itu sendiri. Bahasa Arab di samping berperan sebagai alat komunikasi antar sesama manusia, juga menjaga hubungan komunikasi seorang mukmin kepada Rabb-nya dalam hal ibadah. Imam asy-Syātịy -rahimahullāh- telah menegaskan pentingnya mempelajari bahasa Arab untuk memahami Islam, beliau berkata (yang artinya): "Sesungguhnya syariat yang mulia dan diberkahi ini (Islam) berbahasa Arab, bagi siapa yang ingin memahaminya hendaklah memahami sebagaimana lisan Arab memahamimya, tidak ada jalan lain bagi penuntut ilmu -yang hendak memahami syariat ini- selain melalui jalur ini."

Bahasa Arab senantiasa berkembang (dinamis-progresif) menjadi berbagai cabang ilmu, beraneka macam konsentrasi, dan seluk beluk permasalahannya yang mendetail. Hal ini karena bahasa merupakan realitas sosial yang hidup dan berkembang seiring dengan perkembangan manusia itu sendiri. ${ }^{7}$ Beberapa cabang ilmu bahasa Arab yang terdokumentasi dan ban-

4 Acep Hermawan, Metodologi Pembelajaran Bahasa Arab, (Bandung: PT Remaja Rosdakarya, 2013), hlm. 111.

5 Sebagaimana tersirat dalam sebuah kaidah ushul

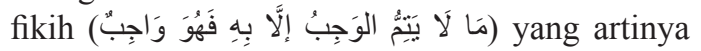
"Segala sesuatu yang kewajiban tidak sempurna kecuali dengan melakukannya, maka sesuatu tersebut wajib dilakukan." Juga terdapat kaidah yang senada dengannya (الََسائلُْ لَهَا أَحْكَامُ المَقَاصِدِ). Taisīr Ușūl Fiqh Li Al Mubtadi'īn, hlm. 2/14., dan Al-Qarafi dalam Al-Furūq, hlm. 3/111-112. Kaidah ini telah tersirat dalam al-Qur'an di QS. Al-Taubah: 120, Al-Ahzab: 32, dan al-Nur: 31.

6 Asy-Syāṭibiy, Al-Muwāfaqāt fi Ușūl asySyarī'ah, (Beirut: Al-Maktabah al-'Ashriyyah, 2013), hlm. 2/49.

7 Acep Hermawan, Metodologi ..., hlm. 24. yak dipelajari adalah ilmu nahwwu, șaraf, dan balāgah. Dalam pembelajaran bahasa Arab tidak lepas dari strategi penyampaiannya, sehingga muncul beberapa metode seperti; simā'iy (pendengaraan), hizwār/muhādasiah (percakapan), ta'bìr (pengungkapan), kitābah (penulisan), qirā'ah/muthāla'ah (pembacaan), tahlīl i’rāb (analisa kedudukan kata), serta macam-macam metode lainnya, semua aspek tersebut bermuara ke pemahaman alQur'an dan al-Hadits.

Salah satu aspek yang menarik perhatian ulama adalah masalah $i^{\prime} r \bar{r} b$, selain menjadi salah satu karakteristik bahasa Arab yang tidak terdapat di bahasa lainnya, ${ }^{8}$ serta terdapat keterkaitan antara i'rāb tersebut dengan makna dari i'rāb al-Qur'an, selain itu keterampilan i'rāb sendiri merupakan indikator utama seorang penuntut ilmu menguasai bahasa Arab, mengetahui makna-makna yang terkandung di dalam ayat-ayat dan membedakannya. ${ }^{9}$ I'rāb merupakan sebuah alat yang dengannya seseorang mampu mencapai derajat kefashihan berbahasa Arab, dan melaluinya penuntut ilmu bisa mengetahui maknamakna yang terkandung dalam nuṣūs (teks) dan maqāṣid (konteks) dari susunan lafadz, ${ }^{10}$ sehingga hal ini membangkitkan motivasi para ilmuwan dalam menulis kitab-kitab i'rāb al-Qur'an.

Di beberapa pondok pesantren, khususnya lembaga pendidikan bahasa Arab di Indonesia telah menerapkan berbagai macam model pembelajaran bahasa Arab sesuai dengan orientasinya dan mampu beradaptasi dengan kondisi lingkungan yang mencocokinya; bahkan sudah di mulai sejak PAUD (Pendidikan Anak Usia Dini), hingga perguruan tinggi. ${ }^{11}$

8 Fathur Rohman, Metodologi Pembelajaran Bahasa Arab, (Malang: Madani KIP, 2015), hlm. 13.

9 Abu al-Faḍl 'Abdu al-Raḥmān Jalāl ad-Dīn asSuyūtịy, Al-Itqān fi 'Ulūm al-Qur'ān, (Al-Qāhirah: Maktabah Mișr).

10 Muḥammad 'Afīfuddīn Dimyāțiy, Șafā'u alLisān fi I'rāb al-Qur'ān, (Sidoarjo: Maktabah Lisān 'Arabiy, 2016), hlm. 4.

11 Acep Hermawan, Metodologi ..., hlm. 89. 
Meskipun Pendidikan Bahasa Arab (PBA) di Indonesia tersebar di berbagai instansi pendidikan, namun disiplin keilmuan ini cenderung lemah; baik dari faktor sumber daya manusia, lingkungan, kurikulum, serta perangkat-perangkat pendukungnya yang tidak selaras.

Tujuan pembelajaran bahasa Arab secara umum adalah agar siswa mampu mengusai empat mahärah (keterampilan) bahasa yaitu keterampilan menyimak, membaca, berbicara, dan menulis. Untuk memperoleh keempat keterampilan ini, ada beberapa hal yang perlu diperhatikan oleh pendidik, salah satu faktor terpenting adalah metode mengajar.

Fenomena yang terjadi di kalangan mayoritas santri yang telah cakap membaca, menulis, dan fasih berbicara dengan bahasa Arab, bahkan sebagian siswa telah selesai menghafal al-Qur'an, akan tetapi mereka tidak terbiasa dengan meng-i ${ }^{\prime} r \bar{a} b$ susunan kalimat sederhana, terlebih apabila langsung berhadapan dengan al-Qur'an, yang akhirnya muncul pada peserta didik/ santri perasaan canggung dan pesimis untuk memasuki pintu ini. Kelemahan ini mendesak untuk segera dibenahi dengan memberikan keterampilan "plus" selain keterampilan berbahasa Arab aktif, juga keterampilan mengupas "isi" al-Qur'an melalui pendekatan i'rāb al-Qur'an.

Risalah ini berusaha mengungkap, mendeskripsikan, sekaligus upaya menemukan model pembelajaran bahasa Arab li al nā iqin bigairihā (bagi penutur non-Arab), bertujuan untuk memenuhi tantangan sekaligus harapan khususnya dalam pendidikan bahasa Arab agar lebih edukatif dan efektif salah satu formulanya yaitu dengan pendekatan i'rāb al-Qur'an; di mana metode ini diharapkan menjadi pelengkap dan penyempurna dari metodemetode pembelajaran bahasa Arab yang ada, yang diperuntukkan bagi pelajar di tanah air khususnya dan mancanegara pada umumnya. Dengan demikian ada beberapa faktor mengapa metode i'rāb al-Qur'an dan konvensional perlu dibahas, berikut beberapa indikatornya, Pertama; bahasa
Arab adalah bahasa yang telah Allah pilih sebagai bahasa pengantar bagi umat Islam dalam memahami wahyu (al-Qur'an dan al-Hadits). Ada kurang lebih sepuluh ayat dalam al-Qur'an menunjukkan bahwa alQur'an diturunkan dalam bahasa Arab, ${ }^{12}$ dan sebagai landasan sekaligus motivasi seorang muslim untuk mempelajari dan memakainya dalam kehidupan sehari-hari baik percakapan maupun peribadatan.

Kedua; metode i'rāb al-Qur'an (IQ) menjadi pilihan dalam kajianini, sebab selain sebagai indikator kecakapan gramatikal juga bahasa Arab sendiri tidak bisa berdiri tanpanya-menurut mayoritas ahli bahasaSelain itu terdapat hubungan i'rāb dengan perubahan makna, dan ia memiliki fungsi utama; yaitu menjaga kefashihan ${ }^{13}$ bahasa Arab yang bersumber dari al-Qur'an dan al-Hadiø, sehingga ia salah satu pilar ilmu bahasa Arab yang berupaya melestarikan kemurnian keduanya, selain itu juga membantu siswa senantiasa terikat dengan Rabb-nya melalui kitābullāh.

Ketiga; metode konvensional lazimnya dipakai mayoritas pembelajaran di pondok-pondok pesantren berbasis salaf -khususnya- sebagai metode standar layaknya gabungan antara metode ceramah dengan kaidah-terjemah yang memiliki tujuan utama yaitu untuk studi Islam. metode kovensional atau nama lainnya adalah klasik maupun tradisional, merupakan metode paling tua yang dipakai umat Islam sejak turunnya wahyu. Metode ini cocok dengan metode i'rāb al-Qur'an sebagai pengembangannya; sebab materi pembelajaran bahasa Arab di pendidikan pesantren berbasis salaf umumnya dimulai dengan hafalan qawā'id (kaidah-kaidah) dasar bahasa -sembari menghafal alQur'an-; ilmu narwu (sintaksis), raraf

12 QS. 12:2, 13:37, 20:113, 39:28, 41:3, 42:7, 43:3, 46:12, 26:195, 16:103.

13 Bahasa fashīh, atau fuṣhah; adalah bahasa formal (ragam standar), disebut juga bahasa al-Qur'an, karena penggunaan bahasa fushhah harus menggunakan ilmu tata bahasa Arab (ilmu nahwu dan șaraf). Acep Hermawan, Metodologi...., hlm. 7273. 
(morfologis), balāgah (semantik), kemudian setelahnya santri/siswa beralih ke pemahaman "kitab kuning" (teks berbahasa arab) seperti aqidah, tafsir, hadits, fiqih, siroh, dan selainnya disertai dengan tazwid al-mufradāt (hapalan kosakata). ${ }^{14}$

Keempat; umumnya para siswa dalam pembelajaran bahasa Arab khususnya terkait dengan keterampilan i'rāb di mayoritas lembaga pendidikan Islam terpadu/program unggulan; mereka terlebih dahulu diajak mempelajari kaidah-kaidah dasarnya dari kitab-kitab dasar. Setelah seseorang menguasai semuanya, baru mulai tahapan mengkaji ke sumbernya yaitu alQur'an maupun al-Hadiø. Hal ini cenderung memerlukan jam pembelajaran yang lebih panjang untuk menguasai kandungan alQur'an sekaligus mengerti $i$ 'rāb-nya. Perkara ini akan tampak berbeda ketika seorang penuntut ilmu diajak langsung berhadapan dengan sumbernya, sehingga akan mengubah mind-set pembelajaran dalam proses belajar bahasa Arab umumnya. Variasi konsep ini diharapkan menjadi motivasi yang menjauhkan kejenuhan bagi seorang penuntut ilmu, sehingga mereka sembari menghafal al-Qur'an dan mengkaji maknanya sekaligus belajar bahasa Arab melalui metode IQ ini.

Kelima; tulisan ini berusaha mengungkap metode IQ bilamana di implementasikan ke pembelajaran bahasa Arab di madrasah atau pesantren dan mencari perbedaan pembelajaran bahasa Arab dengan pendekatan i'rāb al-Qur'an dan konvensional li al-nā (bagi penutur non-Arab).

Berdasarkan beberapa indikator tersebut maka peneliti menganggap pembahasan ini sangat urgen dan insya Allah bermanfaat bagi dunia pendidikan Islam secara umum, juga dalam aspek pembelajaran bahasa Arab khususnya agar menjadi lebih kaya, efektif, dan efisien. Hipotesis dari penelitian ini; 1) Variasi metode belajar bahasa Arab dengan Metode

14 Bisri Mustofa, M. Abdul Hamid, Metode dan Strategi Pembelajaran Bahasa Arab, (Malang: UIN-Maliki Press, 2016), hlm. 9.
Konvensional (MK) dan Metode Irāa alQur'ān (IQ) membantu peserta didik dalam proses pembelajaran untuk mencerna pelajaran bahasa Arab dengan baik. 2) Berinteraksi dengan al-Qur'an secara langsung akan memudahkan penerjemahan dan memahaminya dengan pemahaman yang tepat, serta memotivasi pelajar menjaga hafalannya.

\section{METODE PENELITIAN}

Berdasarkan rancangan/desain penelitian, bisa dikelompokkan menjadi; 1) penelitian eksperimental, dan 2) penelitian non-eksperimental. Penelitian ini menggunakan penelitian eksperimental. Dalam praktiknya, akan dibuat dua kelompok; kelompok I adalah santri yang akan diberi model pembelajaran bahasa Arab dengan metode IQ, disebut juga sebagai kelompok eksperimen (ㅇ๐)○○(

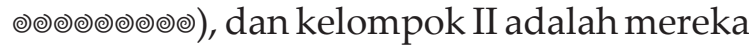
yang mendapat model pembelajaran bahasa Arab dengan metode konvensional, grup ini disebut juga dengan controlled group

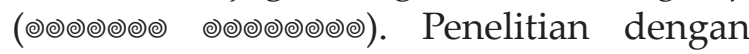
pendekatan kualitatif, data yang akan dianalisis berupa fenomena atau perilaku dalam sebuah penyajian berbentuk esai atau uraian. Apabila terdapat angka-angka yang diperoleh dari tes adalah sebagai data penunjang. Ada tiga tahap dalam analisis data ini, yaitu tahap pengelolaan data, tahap pengorganisasian data, dan tahap penemuan hasil. ${ }^{15}$ Dalam penelitian ini akan dipaparkan data tentang pola interaksi di kelas antara pengajar dan pembelajar, juga antar siswa itu sendiri terhadap dampak dari kedua model pembelajaran.

\section{Gambaran Umum Pondok Pesantren Al Madinah Nogosari Boyolali}

Pondok Pesantren Al Madinah berada di bawah naungan Yayasan Al Madinah yang bergerak di bidang dakwah dan pendidikan. Yayasan Al Madinah merupakan salah satu di antara sekian

15 Moh. Ainin, Metodologi Penelitian Bahasa Arab, (Surabaya: Hilal Pustaka, 2016), hlm. 131-133. 
banyak yayasan Islam yang berlokasi di sebelah selatan SDIT Al Madinah atau di sebelah Utara TKIP Al Madinah, tepatnya di jalan Hamzah 7, RT/RW 04/07, Windan Baru, Gumpang, Kartasura, Sukoharjo, Jawa Tengah, Kode Pos 57169. Yayasan ini didirikan pada tanggal 17 Jumadil Akhir $1417 \mathrm{H}$, bertepatan dengan 30 September $1996 .{ }^{16}$

Yayasan Al Madinah memiliki empat bidang program kerja; Pertama, di bidang pendidikan mengadakan serangkaian program kerja di antaranya adalah mendirikan lembaga-lembaga pendidikan formal seperti sekolah resmi dengan sistem tingkatan kelas. Kedua, bidang dakwah dan sosial, mewujudkan pendidikan informal seperti mengadakan dauroh (tabligh akbar) atau pelatihan ilmiah, halaqah atau majelismajelis ta'lim secara rutin, membentuk persatuan takmir masjid, dan program santunan bagi anak yatim dan fakir miskin. Ketiga, bidang usaha yang berkonsentrasi di usaha produktif, percetakan dan penerbitan, dan Keempat, adalah bidang penelitian dan pengembangan. ${ }^{17}$

\section{HASIL PENELITIAN DAN PEMBAHASAN} Model Pembelajaran Bahasa Arab Madrasah Aliyah Al Madinah

Metode pembelajaran oleh Sahkholid Nasution secara garis besar diklasifikasikan menjadi dua model, yang pertama adalah metode pembelajaran konvensional atau tradisional, dan kedua adalah metode pembelajaran inkonvensional atau modern. Metode pembelajaran konvensional atau tradisional adalah metode mengajar yang umum dipakai para pengajar dengan pendekatan klasikal, guru sebagai media utama pentransfer ilmu dan penentu jalannya proses pembelajaran, sedangkan siswa adalah penerima ilmu yang disampaikan guru. ${ }^{18}$

16 Pengurus Yayasan Al Madinah Periode 20072010, Laporan Perkembangan Yayasan Al Madinah Surakarta s.d. 2009, Dokumentasi Milik Yayasan Al Madinah (tt), hlm. 2.

17 Ibid.

18 Nasution, Sahkholid, Metode Konvensional Dan
Metode inkonvensional atau modern adalah sebuah metode pembelajaran yang baru berkembang dan belum lazim digunakan secara umum, masih merupakan metode yang baru dikembangkan -sebagai penyempurna metode-metode sebelumnyadan diimplementasikan di beberapa sekolah tertentu yang mempunyai peralatan lengkap dan media pendukungnya, metode ini membutuhkan guru-guru profesional yang ahli di bidangnya. ${ }^{19}$

Madrasah Aliyah Al Madinah Pilangsari Boyolali menetapkan sistem pendidikan full day school atau dikenal dengan pesantren yang mana proses pendidikan berlangsung dari pagi siswa bangun tidur hingga malam saat mereka tidur kembali. Metode yang digunakan para ustadz adalah metode bandongan yaitu metode kolektif (halaqoh) penyampaiannya dengan model kaidah-terjemah yang mana ustadz membaca kitab berbahasa Arab, lalu menerjemahkan dan menjelaskan kaidahkaidah dan hikmah yang terkandung di dalamnya, sementara para santri menyimak kajian yang disampaikan ustadz. Di akhir acara, terkadang sang ustadz melemparkan beberapa pertanyaan secara langsung kepada santri yang bermajelis di depannya, demikian pula saat akan mulai taklim di hari berikutnya, sang ustadz menanyakan beberapa santrinya perihal tema yang telah diajarkan sebelumnya.

Pembelajaran saat di kelas, pondok Al Madinah menganut sistem pembelajaran aktif, meskipun sebagian besar pengajaran di MA Al Madinah masih didominasi dengan metode konvensional, di mana guru lebih banyak berceramah dan melakukan tanya-jawab kepada santrinya secara langsung (al-tarīqah al-mubāsyirah). Namun para asatidzah MA Al Madinah khususnya guru bahasa Arab masing-masing memiliki keunikan tersendiri dan metodenya yang khas. Untuk mengoptimalkan kemampuan santri memahami materi berbahasa Arab

Inkonvensional Dalam Pembelajaran Bahasa Arab, dalam Jurnal Ilmiah Didaktika: Februari 2012, Vol. XII, No. 2: 259-271.

19 Ibid. 
(karena kurikulum kepondokan ratarata berbahasa Arab) maka pondok $\mathrm{Al}$ Madinah menekankan santrinya untuk aktif berbahasa Arab dalam kesehariannya di lingkungan pondok pesantren, dari tingkat SMP dan MA.

Kurikulum bahasa Arab di MA Al Madinah meskipun memakai buku ajar bahasa Arab dari Depag dengan metode nadzariyatu wihdah, namun PBM (Proses Belajar Mengajar) di sekolah lebih banyak mengadopsi kurikulum Saudi Arabia seperti kitab silsilah ta'lim yang memakai sistem nadzariyatu furu', konsekuensinya pelajaran bahasa Arab di MA Al Madinah dipecah menjadi beberapa sub materi, yaitu muțāla'ah, ta'bìr, naḥwu, șaraf, dan balāgah.

Masing-masing sub pelajaran bahasa Arab diampu oleh guru/ ustadz yang berbeda. Strategi pembelajaran formal oleh masing-masing guru terdiri dari tiga kemampuan utama (aspek pedagogik), yaitu kemampuan perencanaan materi, kemampuan pengajaran, dan kemampuan evaluasi.

Mayoritas guru mengajarkan bahasa Arab dengan indirect method sebab didapati banyak siswa yang kesulitan memahami penjelasan materi pelajaran. Namun demikian, pada sebagian kondisi, sang guru terkadang menggunakan metode langsung berkomunikasi dan menjelaskan mufradāt (kosa kata) kepada siswanya dengan sinonim dan antonim bahasa Arab (eklektik). Hasil penelitian yang berkaitan dengan model pembelajaran bahasa Arab li al-nātiqīin bi gairihā (bagi penutur non-Arab) yang digunakan selama ini menggunakan model konvensional sebagaimana di pondok pesantren klasik umumnya. Pembelajaran menggunakan metode kaidah-terjemah, penyampaian dengan lecturer (ceramah), tanya-jawab dan talaqqi (bandongan dan sorogan).

Model pembelajaran yang digunakan dalam bahasa Arab li al-nāțiqīn bi gairihā (bagi penutur non-Arab) seperti metode I'rābul Qur'ān (IQ) dan I'rabul Hadīis (IH) dengan cara menyebutkan ayat dan hadits yang di dalamnya terdapat poin-poin pembahasan yang sedang dikaji kemudian menjelaskan secara rinci bentuk akar kata dari kalimat-kalimat yang ada pada ayat dan hadits yang dibawakan, kemudian meminta kepada beberapa murid untuk menjelaskan beberapa kata yang telah dijelaskan sebelumnya atau yang sesuai dengan pembahasan yang sedang dikaji.

Menggunakan metode IQ merupakan metode favorit bagi guru. Model ini Guru lebih aktif selaku pemberi ilmu, dan murid menerimanya, dengan menyimak dan mencatat penjelasan dari pengajar. Untuk pelajaran muțāla'ah ditambah dengan menggunakan metode presentasi dan diskusi. Sarana pembelajaran yang digunakan dalam mendukung model pembelajaran seperti proyektor dan laptop, kamus $M a^{\prime} \bar{a} n i$ al-Alfādz, kitab-kitab Hadits, kamus al-Qur'an juga dengan mata pelajaran lain yang masih satu rumpun; seperti nahwwu, șaraf, dan balāgah. Sarana pembelajaran yang digunakan dalam mendukung model pembelajaran seperti papan tulis dan alat tulisnya, LCD (slide), laptop/notebook, alQur'an, kitab-kitab Hadis, kamus dan lainlain.

Dilihat dari sarana dan prasarana untuk unit MA Al Madinah Nogosari yang ada kaitannya dengan metode atau pembelajaran adalah proyektor. Dimana proyektor sudah memiliki 5 unit. Apabila dilihat dari jumlah kelas sebanyak 6 rombel maka dengan tersedianya proyektor sebanyak 5 unit diharapkan disetiap pembelajaran bisa menggunakan proyektor sehingga pembelajaran lebih berbeda dengan pembelajaran konvensional.

Penggunaan metode I'rāb al-Qur'an (IQ) ada hambatannya seperti; 1) Waktu yang terbatas, 2) SDM yang kurang memadai, 3) Kurangnya motivasi siswa dalam belajar. Selain itu hambatan klasik yang sering muncul adalah pelajar yang malas dan tidak mau muroja'ah (mengulang pelajaran). I'rāb merupakan sebuah alat yang dengannya seseorang mampu mencapai derajat kefashihan berbahasa Arab, dan melaluinya penuntut ilmu bisa mengetahui maknamakna yang terkandung dalam nușuṣ (teks) 
dan maqū $-i d$ (konteks) dari susunan lafadz, sehingga hal ini membangkitkan motivasi para ilmuwan dalam menulis kitab-kitab i'rāb al-Qur'an.

Solusi dari hambatan tersebut adalah 1) Menentukan tujuan pembelajaran bahasa Arab yang lebih spesifik, 2) Mengatur ulang jadwal dan review ulang buku ajar menyesuaikan tujuan pembelajarannya, 3) Membuat khulashoh (ringkasan) materi sesuai dengan kondisi dan kebutuhan, 4) Menggunakan strategi campuran di samping metode yang ada pada guru untuk meminimalisir kejenuhan belajar siswa. 5) Menganalisa sebab hambatan yang ada dan melengkapi kekurangan yang ada dengan mengulangi kembali penjelasan tentang materi tersebut. 6) Drill (tadribat).

\section{Perbedaan Antara Metode I'rāb al-Qur'an Dengan Metode Konvensional}

I'rab merupakan salah satu unsur dari unsur-unsur yang tidak dapat dikesampingkan dalam mengetahui makna yang terkandung oleh struktur kalimat. Metode i'rāb al-Qur'an di terapkan di lingkungan pondok pesantren dalam pembelajaran nahwwu, saraf, balāgah dan beberapa di pelajaran muțāla'ah. Langkahlangkah metode IQ sebagai berikut.

1. Menyesuaikan kurikulum sub materi yang dipelajari, contoh pelajaran balāgah, di dalamnya terdapat bab pelajaran ilmu ma'ani di dalamnya terdapat sub bab seperti khobar dan insya', dan ilmu bayan dengan sub bab materi seperti tasybīh dan isti'ārah.

2. Peserta didik diajak memahami gambaran umum apa yang akan dibahas di sub ini.

3. Guru menjelaskan contoh-contohnya menggunakan kutipan ayat-ayat Qur'aniyyah maupun Hadis dalam aplikasinya.

4. Guru mengulangi materi dengan pertanyaan-pertanyaan.

5. Mencari syawahid berupa ayat-ayat yang ada pada pembahasan sesuai urutan kurikulum kemudian memaparkan dihadapan kelas ayat-ayat tersebut dan menjelaskannya.

Temuan tersebut sesuai dengan pendapat Mahmud Yunus (1990) dan Muhammad 'Aliy Abu al-'Abbās (1998) bahwa IQ dapat dilakukan dengan beberapa langkah berikut; Pertama adalah motivasi siswa untuk membaca ayat dengan Qira'at Hafs sesuai hukum tajwid, guru mencontohkan lalu murid menyimak dan mengikuti bacaannya. ${ }^{20}$ Kedua; I'rab merupakan cabang makna, untuk itu pengajar terlebih dahulu menyajikan terjemahan ayat yang hendak di-i'rab, sehingga pelajar memahami arti yang diinginkan ayat dengan melihat terjemahannya, dan akan lebih baik jika diberi asbāb al-nuzūl jika ada kaitannya dengan ayat tersebut. Hal ini dilakukan untuk menghindari dari kesalahan dalam meng-i'rab ayatal-Qur'anmaupunal-Hadiș. ${ }^{21}$ Ketiga; tazwìd al-mufradāt dengan membekali siswa tambahan kosa kata sesuai dengan tema ayat. Keempat; analisa i'rab setiap kata dan susunannya sesuai dengan ilmu nahwu, șaraf, dan balāgah. Ketiga ilmu ini dipilih untuk menyesuaikan standar kaidah bahasa Arab kurikulum 2013 Kementerian Agama untuk Madrasah Aliyah jurusan keagamaan di Indonesia. Kelima adalah evaluasi dengan memberikan pertanyaan-pertanyaan sesuai tema ayat.

Perbedaan metode IQ dengan metode konvensional terletak di dalam penyajian contoh-contoh materinya. Metode IQ lebih mengajak siswa berinteraksi secara langsung kepada al-Qur'an maupun alHadits, mempelajari huruf al-Qur'an sesuai dengan tajwid, dan metode IQ lebih fleksibel dan luas pembahasannya, adapun metode konvensional terbatas dengan kitab

20 Mahmud Yunus, Metodik Khusus Bahasa Arab -Bahasa Al-Qur'an-, (Jakarta: PT. Hidakarya Agung, 1990), hlm. 5

21 Muhammad 'Aliy Abu al-'Abbās, Al-I'rāb al-Muyassar; Dirāsat fi al-Qawā'id wa alMa'āniy wa al-I'rāb Tajma' Baina al-Așālati wa al-Mu'āṣarah, (Al-Qāhirah: Dār Al-Ṭalā'i', 1998), hlm. 7. 
kurikulum pegangan. Metode IQ akan lebih efektif, jika pengajar telah menguasai metode konvensional sebagai metode dasar yang telah dipaparkan pada point pertama.

Sebagaimana pendapat Yusuf bin Khalaf al-'Aisawiy (2007) bahwa metode IQ sangat fleksibel dalam pengembangannya, baik secara ijmāliy, tafșìliy, tahlīiliy, maupun maudü'iy'22. Dalam praktiknya, setiap ayat bisa ditambah fariabelnya sesuai kebutuhan, seperti dikaitkan dengan materi keagamaan (IMTAQ) seperti tafsir, aqidah, fiqih, akhlaq, sastra, dan juga aspek inter-text (hubungan ayat dengan hadits), maupun IPTEK. Oleh karenanya dibutuhkan inovasi dan kreatifitas guru dalam pembelajarannya, sehingga mampu menciptakan suasana kelas yang kondusif dan menyenangkan saat proses pembelajaran berlangsung.

Metode konvensional yang dipakai pesantren MA Al Madinah adalah metode

22 Yusuf bin Khalaf al-'Aisāwiy, Ilmu I'rāb alQur'an; Ta'șilluhu wa Bayānuhu, (Riyad: Dār al-Șumai'iy, 2007), hlm. 164. ceramah -sebagai metode dasar-, yang kemudian berkembang dan diikuti dengan metode tanya-jawab, diskusi, demonstrasi, kerja kelompok, drill, pemberian tugas, dan lainnya. Karakteristik pembelajaran konvensionaladalah sebagaiberikut:1)Guru sebagai sumber ilmu yang aktif mentransfer ilmu kepada siswa. 2) Guru menganggap siswa pasif dan berkemampuan sama. 3) Menggunakan kelas sebagai satusatunya tempat belajar. 4) Mengajar lebih banyak menggunakan metode ceramah. 5) Pemisahan antar bidang studi nampak jelas. 6) Memberikan kegiatan yang tidak bervariasi. 7) Berkomunikasi dengan satu arah. 8) Iklim belajar menekankan pada pencapaian efek instruksinal berdasarkan orientasi kelompok. 8) Mengajar hanya menggunakan buku sebagai belajar dan informasi dari guru. 9) Hanya menilai hasil belajar.

Berdasarkan pengamatan, terdapat penemuan persamaan dan perbedaan MIQ dan MK adalah sebagai berikut:

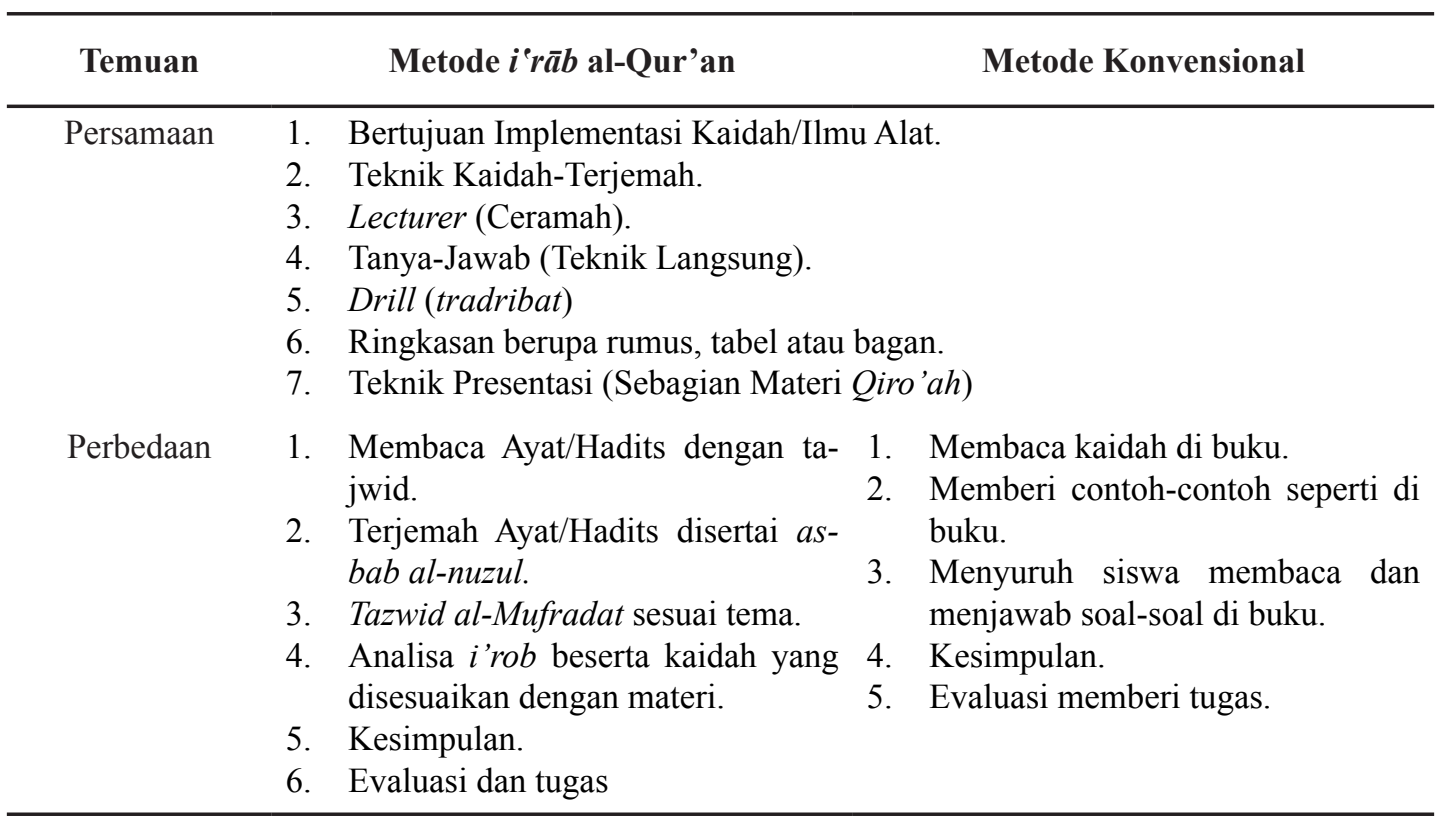

Temuan kelebihan dan kekurangan MIQ dan MK sebagaimana tertera pada tabel berikut: 


\begin{tabular}{|c|c|c|}
\hline Temuan & Metode $I^{\prime} r \bar{a} b$ al-Qur'an & Metode Konvensional \\
\hline Kelebihan & $\begin{array}{l}\text { 1. Baik dalam kompetensi kognitif } \\
\text { dan afektif. } \\
\text { 2. Lebih luas cakupan dan wawasann- } \\
\text { ya. } \\
\text { 3. Menjaga kefashihan dengan menja- } \\
\text { ga tajwid. } \\
\text { 4. Fleksibel. } \\
\text { 5. Bisa inter-teks dengan konteks } \\
\text { kekinian. } \\
\text { 6. Bisa berkolaborasi dengan materi } \\
\text { 7. Efektif dan Efisien. }\end{array}$ & $\begin{array}{l}\text { 1. Baik dalam kompetensi kognitif. } \\
\text { 2. Tidak perlu guru yang kompeten. } \\
\text { 3. Cukup dengan modal kitab. } \\
\text { 4. Bisa mengajarkan lebih banyak } \\
\text { siswa dalam satu kelas. } \\
\text { 5. Mudah dalam evaluasi. }\end{array}$ \\
\hline Kekurangan & $\begin{array}{l}\text { 1. Membutuhkan SDM yang unggul. } \\
\text { 2. Kurang dalam kompetensi kalam, } \\
\text { hiwar (dialog). } \\
\text { 3. Membosankan jika tidak ada kreatif- } \\
\text { itas di dalam kelas. }\end{array}$ & $\begin{array}{l}\text { 1. Cakupan dan wawasannya terbatas } \\
\text { dalam buku ajar. } \\
\text { 2. Tidak bisa berkolaborasi dengan } \\
\text { materi lainnya kecuali masih satu } \\
\text { rumpun. } \\
\text { 3. Hanya fokus pada kognitif. } \\
\text { 4. Membosankan jika tidak ada kreatif- } \\
\text { itas di dalam kelas. }\end{array}$ \\
\hline
\end{tabular}

Efektifitas pembelajaran bahasa Arab untuk non-Arab dengan metode $i^{\prime} r \bar{a} b$ al-Qur'an dan metode konvensional di lingkungan pondok pesantren

Metode i'rāb al-Qur'an (IQ) menjadi pilihan dalam kajian ini, sebab selain sebagai indikator kecakapan gramatikal juga bahasa Arab sendiri tidak bisa berdiri tanpanya -sebagaimana menurut mayoritas ahli bahasa-. Selain itu terdapat hubungan $i^{\prime} r a \bar{b}$ dengan perubahan makna, dan ia memiliki fungsi utama yaitu menjaga kefashihan bahasa Arab yang bersumber dari alQur'an dan al-Hadits, sehingga ia salah satu pilar ilmu bahasa Arab yang berupaya melestarikan kemurnian keduanya, selain itu juga membantu siswa senantiasa terikat dengan Rabb-nya melalui kitābullāh.

Tingkat efektifitas pembelajaran bahasa Arab untuk non-Arab dengan metode $i^{\prime} r a \bar{b} b$ al-Qur'an (IQ) dan metode konvensional (MK) di lingkungan pondok pesantren bahwa metode konvensional kurang memuaskan untuk pelajaran balāgah dan muțāla'ah, jika tidak ada kombinasi strategi. Model metode konvensional yang digunakan di lingkungan pondok pesantren terlihat guru aktif dan menguasai materi maupun suasana kelas. Hasil belajar peserta didik dalam penerapan metode konvensional cukup baik akan tetapi masih kurang memadai. IQ lebih efektif daripada metode konvensional, meskipun hasil belajar peserta didik dalam penerapan metode konvensional cukup baik akan tetapi masih kurang luas wawasanya.

Hasil belajar penggunaan metode i'rāb al-Qur'an dan metode konvensional santriwan kelas XI MA Nogosari Boyolali adalah sebagai berikut: ${ }^{23}$

23 Hasil Dokumentasi Pondok Pesantren Al Madinah.

\begin{tabular}{ccc}
\hline \multirow{2}{*}{ Tahun ajaran } & \multicolumn{2}{c}{ Metode Pembelajaran } \\
\cline { 2 - 3 } & $\boldsymbol{i} \boldsymbol{i} \boldsymbol{r} \bar{b} \boldsymbol{b}$ al-Qur'an & Konvensional \\
\hline $2015-2016$ & - & 82,91 \\
$2016-2017$ & - & 81,62 \\
$2017-2018$ & 81,20 & 82,65 \\
\hline
\end{tabular}

Berdasarkan hasil di atas bahwa metode i'rāb al-Qur'an pada tahun ajaran 2017- 
2018 mempunyai rata-rata nilai sebesar 81,20 sedangkan metode konvensional mempunyai nilai rata-rata sebesar 82,65. Hasil belajar peserta didik dalam penerapan metode konvensional cukup baik daripada metode i'rāb al-Qur'an.

Mempelajari IQ adalah keutamaan selamaseseorang memegang prinsip-prinsip para mufassir (ahli tafsir) yang mu'tabar (kredibel) sebab ia bagian dari tafsir alQur'an dari aspek kebahasaan, terlebih bagi setiap hamba mukallaf (yang telah dibebani syariat) diharuskan mempelajari perkaraperkara yang wajib baginya sehingga dia melaksanakan perintah maupun larangan yang terkandung di dalamnya dengan baik dan benar. Untuk bisa mendapatkan hasil yang terbaik, membutuhkan proses $i^{\prime} t i b \bar{a} r$ (tadabbur) al-Qur'an. Dengan demikian IQ merupakan salah satu alat yang dibutuhkan seorang tâlib al 'ilmi (penuntut ilmu) dalam mentadabburinya, sebab apabila seseorang pelajar salah dalam meng-i'rab (memaknai kandungan) lafad dan susunan ayat alQur'an otomatis akan merubah makna aslinya.

Metode IQ seperti metode tahlīl (analisa) dalam menafsirkan al-Qur'an, namun metode ini lebih menekankan aspek kebahasaan, lebih spesifiknya adalah aspek gramatikal (nahwu-saraf) yaitu mengajarkan siswa sebab-sebab perubahan harakat ( $\mathrm{rafa}^{\prime}$, nashob, jar, dan jazm) di akhir kata atau kalimat. Meskipun keduanya mirip dalam analisa struktur kata dalam kalimat, dan sama-sama memperhatikan harakat akhir lafad serta posisinya, namun terdapat perbedaan dari sisi penisbatan ilmu antara i'rab dengan nahwu; yaitu seperti menyandarkan penyembuhan kepada ilmu kedokteran, atau menyandarkan urusan fatwa kepada ilmu fiqih; sehingga tidak setiap orang yang membaca nahwu mampu meng-i'räb dengan baik, sebagaimana orang yang dapat membaca ilmu kedokteran tidak selalu bisa menyembuhkan penyakit pasiennya, maupun seorang yang faqìh (ahli fiqih) dalam berfatwa.

IQ dapat dilakukan dengan beberapa langkah berikut; Pertama adalah motivasi siswa untuk membaca ayat dengan qirā'at Hafs yang umum dipakai di Indonesia sesuai hukum tajwid, guru mencontohkan dengan membacanya dengan tartìl lalu murid menyimak dan mengikuti bacaannya. Kedua; pengajar terlebih dahulu menyajikan terjemahan ayat yang hendak di-i'rab, sehingga pelajar memahami arti yang diinginkan ayat dengan melihat terjemahannya, dan akan lebih baik jika diberi asbāb al-nuzūl (konteks ayat) jika ada kaitannya dengan ayat tersebut. Hal ini dilakukan untuk menghindari dari kesalahan dalam meng-i'rab ayat alQur'an. Ketiga; tazwìd al-mufradāt dengan membekali siswa tambahan kosa kata baru sesuai dengan tema ayat. Keempat; analisa $i^{\prime} r a b$ setiap kata dan susunannya sesuai dengan ilmu nahwu, saraf, dan balagah. Ketiga ilmu ini dipilih untuk menyesuaikan standar kaidah bahasa Arab kurikulum 2013 departemen Agama untuk Madrasah Aliyah jurusan keagamaan di Indonesia. Kelima; adalah evaluasi dengan memberikan pertanyaan-pertanyaan sesuai tema.

Metode IQ sangat fleksibel dalam pengembangannya, baik secara ijmāliy (umum/ringkas), tafșìliy (rinci), tahlìliy (analisis), maupun maudū'iy (tematik). Dalam praktiknya, setiap ayat bisa ditambah fariabelnya sesuai kebutuhan, seperti dikaitkan dengan materi keagamaan (IMTAQ) seperti tafsir, akidah, fikih, akhlak, sastra, dan juga aspek inter-text (hubungan ayat dengan hadits), maupun IPTEK. Oleh karenanyadibutuhkaninovasidankreatifitas guru mapel dalam pembelajarannya, sehingga mampu menciptakan suasana kelas yang kondusif dan menyenangkan saat proses pembelajaran berlangsung.

\section{KESIMPULAN}

1. Model Pembelajaran Bahasa Arab Madrasah Aliyah Al Madinah Boyolali Tahun 2017/2018. Metode yang digunakan para ustadz adalah metode sorogan dan bandongan yaitu metode kolektif (halaqoh) penyampaiannya dengan model kaidah-terjemah yang 
mana ustadz membaca kitab berbahasa Arab, lalu menerjemahkan dan menjelaskan kaidah-kaidah dan hikmah yang terkandung di dalamnya, sementara para santri menyimak kajian yang disampaikan ustadz. Pembelajaran saat di kelas, pondok Al Madinah menganut sistem pembelajaran aktif, meskipun sebagian besar pengajaran di MA masih didominasi dengan metode konvensional, di mana guru lebih banyak berceramah dan melakukan tanya-jawab kepada santrinya secara langsung (al-țarīqah al-mubāsyirah). Namun para asatidzah MA khususnya guru bahasa Arab masing-masing memiliki keunikan tersendiri dan metodenya yang khas. Model pembelajaran bahasa Arab li al-nātiqīn bi gairihā (untuk non-Arab) yang digunakan selama ini menggunakan model konvensional sebagaimana di pondok pesantren klasik umumnya; pembelajaran menggunakan metode kaidah terjemah, penyampaian dengan lecturer (ceramah), tanya-jawab dan talaqqi (sorogan dan bandongan).

2. Perbedaan antara metode i'rāb alQur'an dengan metode konvensional bahwa metode IQ di terapkan di lingkungan pondok pesantren dalam pembelajaran naḩwu-șaraf, balāgah, dan beberapa di pelajaran mutāla'ah. Metode IQ lebih mengajak siswa berinteraksi secara langsung kepada alQur'an maupun al-Hadits. Metode IQ lebih luas pembahasannya, dan siswa lebih mudah mengingat contoh-contoh dan aplikasi ayat-ayat al-Qur'an maupun al-Hadits, adapun konvensional terbatas dengan kitab kurikulum pegangan. Metode IQ lebih efektif, jika pengajar telah menguasai metode konvensional yang telah dipaparkan pada point pertama. Metode IQ lebih luas pembahasannya, adapun konvensional terbatas dengan kitab kurikulum pegangan. Sedangkan metode konvensional yang dipakai pesantren MA Al-Madinah adalah metode ceramah, yang kemudian berkembang dan diikuti dengan metode tanya-jawab, diskusi, demonstrasi, kerja kelompok, drill, pemberian tugas, dan lainnya.

3. Tingkat efektifitas pembelajaran bahasa Arab untuk non-Arab dengan metode i'rāb al-Qur'an dan metode konvensional di lingkungan pondok pesantren bahwa metode konvensional kurang memuaskan untuk pelajaran balāgah dan muțāla'ah, jika tidak ada kombinasi strategi. Model metode konvensional yang digunakan di lingkungan pondok pesantren terlihat Guru aktif dan menguasai materi maupun suasana kelas. Hasil belajar peserta didik dalam penerapan metode konvensional cukup baik akan tetapi masih kurang memadai. Metode i'rāb al-Qur'an lebih efektif daripada metode konvensional, walaupun hasil belajar peserta didik dalam penerapan metode konvensional cukup baik akan tetapi masih kurang luas wawasanya.

\section{DAFTAR PUSTAKA}

Abu al-'Abbās, Muhammad 'Aliy. 1998. Al-I'rāb al-Muyassar; Dirāsat fi al-Qawā'id wa alMa'āniy wa al-I'rāb Tajma' Baina al-Așālati wa al-Mu'āṣarah. Al-Qāhirah: Dār Al-Ṭalā'i'. Al-'Aisāwiy, Yusuf bin Khalaf. 2007. Ilmu I'rāb al-Qur'an, Ta'ṣīluhu wa Bayānuhu. Riyad: Dār al-Shumai'iy.

Bisri Mustofa, M. Abdul Hamid. 2016. Metode dan Strategi Pembelajaran Bahasa Arab. Malang: UIN-Maliki Press.

Dimyāṭiy, Muhammad 'Afīfuddīn. 2016. Ṣafā’u al-Lisān fi I'rāb al-Qur'ān. Sidoarjo: Maktabah Lisān 'Arabiy.

Al-Fawzan, Abdurrahman bin Ibrahim. 1431H. Idhā'āt li Mu'allimi al-Lughah al-'Arabiyyah 
Lighairi an-Nāthiqīn Bihā. Riyadh: Al-'Arabiyyah lil Jamī' .

Hanani, Nurul. 2015. Model Pembelajaran Bahasa Arab Di Pondok Pesantren Salaf Kediri Dan Kontribusinya Terhadap Kemampuan Membaca Teks Berbahasa Arab Bagi Santri, dalam Jurnal Realita: Vol. 13, No. 1 Januari 2015: 81-96.

Hermawan, Acep. 2013. Metodologi Pembelajaran Bahasa Arab. Bandung: PT Remaja Rosdakarya.

Katsīr, Ibnu. Tafsīr al-Qur'an al-'Adzhīm. Jeddah: Maktabah Jeddah.

Kementerian Urusan Agama Islam Kerajaan Saudi Arabia. 1418H. Al-Qur'ān Dan Terjemahnya. Madinah: Mujamma' Malik Fahd.

M. Arif Rahman Hakim, Dedi Efrizal. 2016. Pengembangan Materi Bahan Ajar Public Speaking berdasarkan Communicative Language Teaching, dalam Jurnal Manhaj, Vol. 4, Nomor 3, September-Desember 2016.

Mukroji. 2014. Metode Tamyiz, Sebuah Formulasi Teori Nahwu Shorof Quantum, dalam Jurnal Kependidikan, Vol. 2, No. 1, Mei 2014.

Nasution, Sahkholid. 2012. Metode Konvensional Dan Inkonvensional Dalam Pembelajaran Bahasa Arab, dalam Jurnal Ilmiah Didaktika: Februari 2012, Vol. XII, No. 2: 259-271.

Al-Qatțān, Mannā'. 2000. Mabāhis fi 'Ulūmi al-Qur'ān. Al-Qāhirah: Maktabah Wahbah.

Rohman, Fathur. 2015. Metodologi Pembelajaran Bahasa Arab. Malang: Madani KIP.

Sapri. 2008. Metode Pembelajaran Bahasa Arab: Antara Tradisional dan Modern, dalam Jurnal Insania STAIN Purwokerto: Vol. 13, No. 3, 1 Sep-Des 2008: 441-452.

Sugiyono. 2017. Metode Penelitian Kualitatif. Bandung: CV Alfabeta.

Al-Suyūṭiy, Abu al-Fạ̣l 'Abdu al-Raḥmān Jalāl ad-Dīn. (tt). Al-Itqān fi 'Ulūm al-Qur'ān. AlQāhirah: Maktabah Miṣr.

Al-Syāțibiy, 2013. Al-Muwwāfaqāt fi Ușūl asy-Syarī’ah, Beirut: Al-Maktabah al-'Ashriyyah

Wekke, Ismail Suardi. 2015. Antara Tradisionalisme dan Kemodernan; Pembelajaran Bahasa Arab Madrasah Minoritas Muslim Papua Barat, dalam Tsaqafah, Jurnal Peradaban Islam, Vol. 11, No. 2, November 2015. Ismail Suardi. 2014. Model Pembelajaran Bahasa Arab. Yogyakarta: Deepublish. Ismail Suardi. 2016. Pembelajaran Bahasa Arab di Madrasah. Yogyakarta: Deepublish.

Yunus, Mahmud. 1990. Metodik Khusus Bahasa Arab, Bahasa Al-Qur'an. Jakarta: PT. Hidakarya Agung. 